Guadalupe Soriano Barabino*

\title{
Cultural, textual and linguistic aspects of legal translation: A model of text analysis for training legal translators
}

https://doi.org/10.1515/ijld-2020-2037

Abstract: Legal translation training involves the acquisition and development of a set of sub-competences that constitute legal translation competence (Cao, Deborah. 2007. Translating law. Clevedon: Multilingual Matters; Prieto Ramos, Fernando. 2011. Developing legal translation competence: An integrative processoriented approach. Comparative Legilinguistics. International Journal for Legal Communications 5. 7-21; Piecychna, Beata. 2013. Legal translation competence in the light of translational hermeneutics. Studies in Logic, Grammar and Rhetoric 34(47). 141-159; Soriano Barabino, Guadalupe. 2016. Comparative law for legal translators. Oxford: Peter Lang; Soriano Barabino, Guadalupe. 2018. La formación del traductor jurídico: Análisis de la competencia traductora en traducción jurídica y propuesta de programa formativo. Quaderns: Revista de Traduccio 25. 217-229). The development of those sub-competences is part of a complex process where students are faced with different concepts and translation strategies and techniques which are not necessarily easy to grasp for trainee translators (Way, Catherine. 2014. Structuring a legal translation course: A framework for decisionmaking in legal translation training. In Le Cheng, King Kui Sin \& Anne Wagner (eds.), The Ashgate handbook of legal translation. Farnham: Ashgate), particularly when applied to a legal context. It is our experience that translation students tend to focus on the product (text production) and do not spend enough time analysing the source text, which results in obvious mistakes in mainly - but not only cultural (legal), textual and linguistic aspects. The interdisciplinary nature of legal translation calls for an integrative model for teaching and learning. The model presented provides trainees with a framework for source text analysis that places the communicative situation and the translation brief at the core from which three fundamental dimensions, based on the aspects mentioned above, develop.

\footnotetext{
*Corresponding author: Guadalupe Soriano Barabino, Department of Translation and Interpreting, University of Granada, AVANTI Research Group, Granada, Spain, E-mail: barabino@ugr.es. https://orcid.org/0000-0002-1134-981X
} 
Elements such as the legal cultures involved, legal text typologies or the level of specialisation of terms and discourse are some of the aspects to be considered, so allowing trainees to achieve a thorough understanding of the source text for a conscious translation. The model will be applied to a specific source text and translation brief.

Keywords: legal translator training, legal translation competence, source text analysis, text typologies

\section{Legal translation training}

Legal translation is interdisciplinary by nature and so is its training. Generally speaking, legal translation training can fit three different scenarios: undergraduate students following a translation degree; postgraduate modern languages or postgraduate law students (of course, other types of students can also be found, such as professional translators wishing to specialise in legal translation, for instance). Although students' background, baggage and interests are different, they normally share common features as far as legal translation training is concerned: they must grasp different concepts, translation strategies and techniques (Way 2014); they tend to focus on the product (target text production) rather than on the translation process; and they are inclined to concentrate on terminology (micro-level) rather than on the whole text (macro-level).

Among the different sub-competences that must be developed in legal translation training, ${ }^{1}$ the analysis of source texts is mainly related with the communicative and textual, intercultural and subject area sub-competences. Clearly all other sub-competences are of utmost importance and must all be combined within the training process (the professional, interpersonal and instrumental subcompetence is particularly important for source text analysis regarding the use of and access to specialised documentary sources in later stages) but will be considered as subsidiary for our aim of creating a model for source text analysis in legal translation training. I will refer briefly to those three sub-competences below.

To be competent from a communicative and textual point of view, legal translators must have a thorough knowledge of common/general and legal language in at least two legal cultures (or legal systems). This refers not only to mastering legal language (terminology, phraseology, concepts) but also common

1 Several models of legal translation competence exist (Šarčević 1997; Cao 2007; Prieto Ramos 2011; Piecychna 2013; Kościałkowska-Okońska 2016; Scarpa and Orlando 2017, among others) but here I am referring to the one suggested by Soriano Barabino $(2016,2018)$. 
language (how to write properly, ability to understand texts written in legalese). They must be familiar with textual conventions and text types as well as with legal discourse and different registers found in legal texts.

Intercultural competence involves understanding legal systems as part of the culture of a particular society, as the law evolves in the same way as society. Translators must also be familiar with the social and political reality of a particular country or region, its traditions and customary law. The development of intercultural competence is also seen as the ability to transfer not only between legal systems but also between legal genres (Balogh 2019: 17).

Subject area competence comprises knowledge of legal families or traditions, legal systems, legal branches within the legal systems, sources of law, concepts, institutions, proceedings, substantive and procedural law, and divergences between legal systems. The degree of knowledge will vary greatly depending on the competence and training stage of the translator. It is to be expected that trainees are not experts in the legal systems involved in the translation process, however they should have the skills necessary to access specialised documentation to solve translation problems.

When students are trained in legal translation they normally have a certain degree of translation competence (or are being trained as translators) what means that trainers do not have to focus on translation training from scratch and some basic concepts and strategies have already been developed. Legal translation training must thus be seen as complementary to this basic training and I will focus on these aspects specific to legal translation in the model suggested.

Before explaining the model, I will briefly concentrate on the main features of legal texts so that we can understand why analysing the source text is so important, not only in translation as a whole, but in legal translation in particular.

\section{Main features of legal texts}

The main aspects that differentiate legal translation from translation in a broad sense are legal language, asymmetries and incongruences between legal systems and text typologies (Borja Albi 2000; Soriano Barabino 2020). Legal texts are written using a particular (legal) language and reflect the legal culture to which they belong so that the analysis of legal texts prior to translation is not only useful but also necessary.

Law expresses itself with its own language formed by terms, expressions and different elements of style or register. Legal language has developed parallel to the history and culture of each society and "legal terminology is system-bound, tied to the legal system rather than to language” (Pommer 2008: 18). However, and as this 
same author states, "legal language is a technical language with particularly close ties to the common language, which significantly heightens its culture-specificity".

Law, as a socio-cultural phenomenon, "is always linked to the culture of a particular society and jurisdiction. Consequently, national legal systems are deeply rooted in a specific legal tradition and legal culture” (Pommer 2008:18). This results in asymmetries between legal systems, often considered to be the main challenge for legal translators (Šarčević 1997).

Given the uncountable legal situations existing, there is an immense variety of legal texts. A vast number of them cannot be considered purely legal but are hybrid texts, not only because law impregnates Politics or Economics (among other areas) but also because legal texts may include elements belonging to areas outside the law (Mayoral Asensio 2002, 2004). However, text awareness is essential for translators. As Trosborg (1997: 17) puts it, the "lack of relevant knowledge of genre, communicative functions, text types and culture may result in distorted translations”. Translators should take conscious decisions and to do so they must master not only the two (or more) cultures involved in the translation process but also the textual conventions of both systems (Bathia 1997).

All these elements that characterise legal translation are found in legal texts. When analysing a legal text we should be able to identify a particular legal language and a legal system and culture. This text has a particular form and has a series of features that identify it with a particular genre. Even if this may seem obvious for experienced translators it is not always as clear for novice translators and part of their training should consist in raising awareness about the characteristics of legal texts so that they can produce correct translations.

\section{A model for source text analysis}

As mentioned before, legal translation students are often overwhelmed by the countless aspects they must take into account when producing a target text and tend to concentrate on the final product, not necessarily paying enough attention to the process itself, thereby neglecting aspects related to culture, language or even textual conventions. Having a reference model with blank spaces to be completed makes them devote some time to analysing the text, which highlights the main elements they must take into account for target text production.

Before explaining the model that I propose it is necessary to explain the different levels in which I divide the translation process from a training perspective: 
1. Source text analysis. This should be the first step in any translation process. The model I suggest in this paper aims at making that analysis easier for trainee translators. It is intended to offer a general overview of the text covering general aspects related to the macro and microstructures of the source text but also to implicit cultural elements. It should also include a conscious choice of the general translation strategies to be applied to the translation process in a particular communicative situation and with a specific translation brief.

2. Access to documentary sources and documentary research. Although this level starts during the source text analysis, it is necessary to commit some time to accessing documentary sources and do as much research as may be necessary to accomplish the translation process. Frequently this phase overlaps with the other stages and continues during the whole translation process.

3. Translation problem solving. At this stage, we must focus on solving specific problems both at macro and micro-levels. Comparative law is particularly useful at this point and translation techniques must be used particularly to solve problems of asymmetry at the micro-level.

4. Translation in the proper sense (understood as the actual writing of the target text).

5. Proofreading and revision of the target text.

Based on the above, I suggest a model of source text analysis aimed at helping students at level 1. Although other models for text analysis exist, such as the one suggested by Elena García (2008) based on four levels (functional, situational, thematic and formal-grammatical) where the result is an exhaustive analysis of the text, the one I suggest has several advantages that make it particularly useful for legal translation training, namely:

- It is a model specially designed for legal texts, focusing on the main difficulties of legal translation (as mentioned above).

- It pays particular attention to the communicative situation and translation brief (Nord 2018).

- It does not require a lot of time or documentary research so that students can easily complete the table below before each translation assignment.

- Although very general, the result is a sort of diagram of the source text where the most relevant elements for its translation are highlighted.

The model is presented as a table with different blanks to be completed by the students before undertaking the next levels of the translation process. This is the empty table (Table 1): 
Table 1: Model for ST analysis in legal translation.

Name of document (ST):

\section{Communicative situation (ST)}

Producer:

Receiver:

Function:

\begin{tabular}{lll}
\hline Cultural aspects & Textual aspects & Linguistic aspects \\
\hline Legal family & Text category: & Level of specialisation: \\
Legal system & Normative texts & - Discourse: legalese or \\
Branch of law & Judicial documents & plain language \\
Public/private law & Administrative texts and & - Terminology \\
Substantive/procedural & documents & (frequency of): \\
law & Public documents (issued & - Specialised terms \\
& or authorised by a certifying officer) & - Semi-specialised terms \\
& Private documents & - General terms \\
& Informative texts & Legal language: \\
& Text genre (ex. statute, & - Normative \\
& contract, will, etc.) & - Judicial \\
& & - Administrative \\
& & - Notarial \\
& &
\end{tabular}

Translation brief:

Receiver (TT):

Reader (TT):

Function (TT):

Translation strategies:

Intra-systemic or inter-systemic translation:

Documentary vs. instrumental translation (Nord 2018):

Other relevant information

The first part of the table focuses on analysing the source text on its own. After indicating the name of the text or document to be translated, students are required to offer basic information about the communicative situation, specifically the producer, receiver and function of the source text. It is important to note that I follow a functionalist approach to translation. Therefore, function, understood as "the use a receiver makes of a text or the meaning that the text has for the receiver" (Nord 2018: 138), is the main guiding principle of the translation process.

The three columns below the communicative situation gather essential information to develop the communicative and textual, intercultural and subject area competences. These are of particular relevance in legal translation and may be 
totally irrelevant in other types of translation, such as translation of scientific texts, for instance (especially and broadly speaking, those aspects related to culture).

The basic cultural elements of the source text that students must be familiar with, so that they can easily locate the text in its cultural environment are the legal system and legal family to which the text belongs. Although this may seem an obvious statement and it is paramount in legal translation to know the legal system we are translating from, it is not always as clear for trainee translators. It is our experience that during their first contacts with legal translation, students tend to associate everything written in a particular language with a specific country, what may undeniably result in inaccurate translations.

Although these are not strictly cultural aspects, after locating the text in its legal culture, students must inform about aspects related to the subject area subcompetence. That is, the branch of law to which it belongs, whether it is a text developing private or public law and if it is a document of substantive or procedural law. The distinction between public and private law, although specific to civil law countries ${ }^{2}$ can be also extended to common law countries. Even if this is not one of their characteristic features and it is not often that the court system is divided into public and private courts, it is always possible to differentiate between matters of public law and those falling under the scope of private law.

Although normally more difficult to identify for novice students, another element is whether the text falls under the sphere of substantive law (the positive law applied) or of procedural or adjective law.

The second column is intended to offer information about text typologies. Students must identify the category and text genre of the text. As there are different text classifications in Translation Studies in general, and in legal translation in particular, and given the importance of mastering the textual conventions in both legal systems, a specific part (Section 4) of this paper is dedicated to this aspect and to explain the classification that I suggest.

The third column focuses on linguistic aspects. Students must analyse three characteristics of the text as far as language is concerned. First, they must consider if the text is written in legalese, that is the formal and technical language used in legal documents, or in plain language, using a language that is more accessible to the general public.

Secondly, they must concentrate on terminology. Generally speaking, legal terms can be specialised, semi-specialised or general (of frequent use in the area). Specialised terms are specific to a certain subject area (in this case, law) even if

2 Public law refers to the relationships established between the Government and the governed and private law relates to the matters arising between individuals, whether they be citizens or corporate bodies/legal entities. 
some of them are also used in general language with a different or similar meaning. Semi-specialised terms usually have a particular meaning in general language and a different one in the subject area (Alcaraz Varó 2001). This feature goes hand-inhand with the one mentioned above: the higher the frequency of specialised terms in a text the more specialised that text is. However, all legal texts include the three types of legal terms indicated to a certain extent.

Thirdly, it is also possible to affirm that there are different legal languages and this is the third aspect to be linguistically marked in our model. Just as texts can be classified according to their textual conventions, texts belonging to different textual categories generally share a language which is somewhat different to other texts falling under a different textual category. For language purposes, we will be talking about five "legal languages" (even if I have identified more text (ategories) $)^{3}$ :

- Normative: language used in statutes, codes, regulations, etc.

- Judicial: language used by the judiciary in the texts issued by the courts and the court administration.

- Administrative: language used by the administration/government in its relations with the general public and by the citizens in their relations with the administration/government.

- Language used in public documents issued or authorised by a public officer (in some countries referred to as notarial language).

- $\quad$ Language used in private documents (such as contracts).

After this brief analysis of the source text, the focus moves to the translation brief. Even if this is not, strictly speaking, an analysis of the source text, it is essential to be aware of the requirements of the assignment and take a series of aspects into account so that the result complies with the expectations of the client. Therefore, basic information about who is going to receive the document and who are the potential readers must be provided. Likewise, it is essential to know the function of the target text, as frequently different communicative goals are intended between source and target texts.

As far as translation strategies are concerned, the communicative situation of the translation brief may call for interaction between different legal systems (a text produced in a particular legal system is translated to be read and/or create effects in a different legal culture), in which case we would be talking about

3 Alcaraz Varó (2001) identifies four different legal Spanish languages (normative, judicial, administrative and the one used by notaries public). I consider that these varieties are applicable to legal language in general, but have added a fifth one, the language found in private documents, such as contracts. 
inter-systemic legal translation, or it may just remain in one legal system (we must transfer one text from one language to another but within the same legal system, as is often the case in European Union Law, for instance). In this case, we would talk about intra-systemic legal translation. This distinction is important as legal asymmetries between legal systems (the main feature of inter-systemic legal translation) is one of the most difficult aspects in this type of translation and also (one of) the most challenging to be understood (and mastered) by novice translators.

Strongly related to this is the fact that during their first contacts with legal translation, students tend to convert a text belonging to a particular source culture to a totally different text written in a different language and adapted to a different culture. Although the particular strategies to be applied to and developed for each translation assignment depend on the translation brief itself it is not often that this shift in source and target culture occurs. However, students often have problems in understanding that their task basically consists of "explaining” a source text written in a particular language and belonging to a given source culture in a different language to readers belonging to a specific target culture.

Another aspect to be taken into account, as far as the general strategy to apply to the translation is concerned, has to do with the function of the translation process and the function of the target text as a result of this, that is documentary versus instrumental translation (Nord 2018). Although most legal texts follow an instrumental process of translation and "the result is a text that may achieve the same range of functions as an original text" (Nord 2018: 50), there may also be cases where the result of the translation process is a text "whose main function is metatextual" and the target text is "a text about a text, or about one or more particular aspects of a text”.

A final space is left in the table so that students can indicate particular features of specific texts. An example of this is whether the text is part of a certain proceeding and must be translated in accordance with particular requirements.

\section{Legal typologies}

Before undertaking the next levels of the translation process, students must have a clear image of the source text and, as such, the text typology must be clearly identified. This is why I have added a specific column on text typology to the model. However, as mentioned above, there is a vast array of legal texts and they can be classified according to several criteria. In Translation Studies, several classifications have been suggested based basically, although not only, on subject and professional areas (Delisle 1980; Snell-Hornby 1988 or Wilss 1988, among others), function (some of the 
most representative classifications are the ones suggested by Hatim and Mason 1990; House 1977 or Reiss and Vermeer 1996), or genres. Among the existing current legal text classifications are the one suggested by Šarčević (1997), who classifies texts according to their function (primarily descriptive, primarily descriptive but also descriptive and purely descriptive) or the one by Tiersma (1999), also based mainly on the text functions (operative, expository and persuasive). It is my belief that these classifications do not offer a clear image of the source text and I am more inclined to use a genre-based typology, such as the one created by the GENTT research group. Obviously, both typologies (function-based and genre-based) can be combined thereby providing a clearer image of the source text.

Before explaining the classification that I suggest it is important to clarify some terms such as text type or genre. In line with Balogh (2019: 20-21), I understand genre as "text used in a particular situation for a particular purpose composed and structured according to the norms accepted by a particular discourse community and thus displaying differences in external format (e.g. newspaper article, essay, contract, etc.)" while text types would be distinguished according to their "rhetorical (and communicative) function (e.g. narrative, descriptive, argumentative, comparative, etc.)". Hence the possibility of combining function-based typologies (text types) and genre-based ones.

The model that I suggest aims to collect information about text genres. I have grouped texts genres in seven broad categories, according mainly to their communicative situation, the producer of the text and the legal language used (see Section 3). As a result, and partly based on the categories suggested by the GENTT research group, I have identified the following:

1. Normative texts: this category includes all texts produced by the legislative or executive powers of the State that impose obligations and duties on the citizens. Some of the genres in this category are constitutions, statutes, regulations, codes, minister orders, etc.

2. Judicial documents: texts issued by the courts and the court administration. Judgments, court orders or petitions, among other texts, are included within this category.

3. Administrative texts and documents: texts and documents issued by the administration (government) in their relations with the general public or by the public in their relations with the government. Some genres in this category are application forms or reports, for example.

4. Public documents (issued or authenticated by a certifying officer): in some countries there are public officers, known as notaries, who are the only ones authorised to issue or authenticate certain documents such as wills or deeds. Documents issued by other public officers such as registrars are also included in this category. 
5. Private documents: documents that regulate certain private law issues and are agreed upon by private individuals be they companies or citizens. The main text genre under this category is the contract.

6. Texts written by legal scholars: this category includes law textbooks, academic papers, legal opinions, etc. The language used in this genre is not purely legal but mostly academic.

7. Informative texts: all kind of texts informing about any legal aspect. These texts are usually aimed at the general public, do not have a high level of specialisation and use plain language.

The table below summarises the categories indicated and show a few examples of genres in each category (Table 2):

Table 2: Categories and genres of legal texts.

Text typologies

\begin{tabular}{ll}
\hline Text category & Text genres* (examples) \\
\hline 1. Normative texts & Constitutions \\
& Statutes \\
& Regulations \\
& Codes \\
2. Judicial documents & Judgements \\
& Court Orders \\
& Petitions \\
3. Administrative texts and documents & Appeals \\
& Application forms \\
4. Public documents (issued or & Reports \\
authenticated by a certifying officer) & Requests \\
& Deeds \\
5. Private documents & Wills \\
6. Texts written by legal scholars & Powers of attorney \\
& Contracts \\
7. Informative texts & Law textbooks \\
\hline
\end{tabular}

\section{Application of the model}

Our aim now is to apply the model explained above to a particular legal text and translation brief. The source text that I have used for this has been created for 
academic purposes only and is based on a sample text that has been manipulated to fulfil our aim. ${ }^{4}$ As shown below, it is a last will and testament made in England. A translation brief is suggested after the text:

\section{THIS IS THE LAST WILL AND TESTAMENT}

of Mary Stewart of 23 Gosling Close, Greenford, Middlesex G13 5RT

1. I revoke all my earlier wills codicils and testamentary dispositions.

2. I appoint John Black of 14 High Street Westminster W18 4FG ("my Trustee") to be Executor and Trustee of my Will.

3. I give the remainder of my estate (out of which shall be paid my funeral and testamentary expenses and my debts) to my Trustee on trust for sale with power to postpone sale without liability for loss (and such estate and the property which currently represents it is referred to in this Will as "my Residuary Trust Fund").

4. My Trustee shall hold my Residuary Trust Fund upon trust to distribute as follows:

a. For my husband Peter White if he survives me or if the forgoing gift fails for any reason then to Paul Smith of 17 Houston Road Harrow Middlesex Ha2 8HY absolutely.

5. The standard provisions of the Society of Trust and Estate Practitioners (2nd Edition) shall apply to my Will.

Signed on the 13th day of May 2017 by Mary Stewart to give effect to this Will in the presence of two witnesses present at the same time who have each signed this Will in the presence of the Testatrix.

Signed:

Mary Stewart

In the presence of:

Witness signature Sarah Hollow

Name of witness Sarah Hollow

Address 6 Bellevue Road

Witness signature William Hill

Name of witness William Hill

Address 8 Springfield Gardens

Harrow Ha6 4DR

Occupation Cook

Translation brief: The deceased Mary Stewart had a property in Spain. Her Trustee needs her last will and testament to be translated into Spanish so that the all formalities required by the Spanish authorities can be accomplished.

4 The sample text that has been manipulated can be found at https://www.rocketlawyer.com/gb/ en/documents/last-will-and-testament [last access 14th September, 2020]. 
As indicated above, the first level in the translation process should consist of the analysis of the source text and for this I will use the model suggested above, as follows (Table 3):

Table 3: Application of model for ST analysis in legal translation to a hypothetical translation brief.

Name of document (ST): Last will and testament

\section{Communicative situation (ST)}

Producer: Mary Stewart.

Receiver: Her heirs, her Trustee and Executor, everyone with an interest in her estate upon her death, public authorities.

Function: To dispose of her estate upon her death.

\begin{tabular}{|c|c|c|}
\hline Cultural aspects & Textual aspects & Linguistic aspects \\
\hline $\begin{array}{l}\text { Legal family: Com- } \\
\text { mon Law } \\
\text { Legal system: En- } \\
\text { gland and Wales } \\
\text { Branch of law: In- } \\
\text { heritance Law } \\
\text { Private law } \\
\text { Substantive law }\end{array}$ & $\begin{array}{l}\text { Text category: } \\
\text { Public document (issued or authorised by a } \\
\text { certifying officer). [In some countries, wills } \\
\text { must be authorised by a certifying officer, in } \\
\text { other cases (as this one), it is made legal if } \\
\text { two witnesses sign it]. } \\
\text { Text genre: Last will and testament. }\end{array}$ & $\begin{array}{l}\text { Level of specialisation: } \\
-\quad \text { Discourse: legalese } \\
-\quad \text { Terminology: abun- } \\
\text { dance of specialised } \\
\text { terms } \\
\text { Legal language: Notarial }\end{array}$ \\
\hline
\end{tabular}

\section{Translation brief:}

Receiver (TT): Mary Stewart's Trustee/Spanish authorities involved in inheritance formalities Reader (TT): Spanish authorities involved in inheritance formalities Function (TT): To accomplish the formalities required by the Spanish authorities upon Mary Stewart's death regarding the property she owned in this country.

Translation strategies:

Intra-systemic or inter-systemic translation: Inter-systemic translation.

Documentary vs. instrumental translation: Instrumental translation.

\section{Other relevant information}

As shown in the table above, all the information required can be easily obtained from a thorough reading of the source text and does not require a great amount of time that may discourage students. As has been mentioned before, this is just a first step in undertaking the translation of the text; it allows students to obtain a general overview of the source text so that they can start to make conscious decisions regarding its translation. 


\section{Conclusions}

Converting a legal source text into a target text is a complex process. Diverse history developments and different ways of understanding social phenomena originate dissimilar legal systems that express themselves in different languages and refer to, often, distinct realities. Legal translation implies deconstructing source legal texts into various elements, legal but also cultural, textual or linguistic, among others, and converting them into a new target text where legal aspects from both the source and the target legal cultures co-exist.

This interdisciplinary nature of legal translation calls for an integrative model of translation, not only from a professional perspective but also from a training perspective. Offering trainees the tools to elaborate correct translations is the basis to have good professionals in the future.

Source text analysis is an aspect to which legal translation students do not necessarily pay enough attention. The model proposed allows for the deconstruction of source texts into the main elements - legal, cultural, textual, linguistic - that must be taken into account when transferring a legal source text into a target text. Although it may not be particularly useful for experienced translators it is so for novice translators who do normally concentrate on the product rather than on the process.

Acknowledgment: The author wishes to acknowledge Dr. Catherine Way (Department of Translation and Interpretation, University of Granada, AVANTI research group) for the language revision of this contribution.

\section{References}

Alcaraz Varó, Enrique. 2001. "La traducción del español jurídico y económico”. Centro virtual Cervantes. Available at: https://cvc.cervantes.es/obref/congresos/valladolid/ponencias/ nuevas_fronteras_del_espanol/1_la_traduccion_en_espanol/alcaraz_e.htm (accessed 14 September 2020).

Balogh, Dorka. 2019. The role of genres and text selection in legal translator training. Studies in Logic 58(1). 17-34.

Bhatia, Vijay. 1997. Translating legal genres. In Anna Trosborg (ed.). Text typology and translation, 203-221. Amsterdam/Philadelphia: John Benjamins.

Borja Albi, Anabel. 2000. El texto jurídico inglés y su traducción al español. Barcelona: Ariel.

Cao, Deborah. 2007. Translating law. Clevedon: Multilingual Matters.

Delisle, Jean. 1980. L'analyse du discours comme méthode de traduction. Cahiers de Traductologie 2. Ottawa: Éditions de l'Université d'Ottawa.

Elena García, Pilar. 2008. La organización textual aplicada a la didáctica de la traducción. Quaderns: Revista de Traduccio 15. 153-167. 
Hatim, Basil \& Ian Mason. 1990. Discourse and the translator. London/New York: Longman. House, Juliane. 1977. A model for translation quality assessment. Tubingen: Gunter Narr. Kościałkowska-Okońska, Ewa. 2016. Implications of translation competence in the legal context: A didactic perspective. Comparative Legilinguistics 27. 33-48.

Mayoral Asensio, Roberto. 2002. ¿Cómo se hace la traducción jurídica? Puentes 2. 9-14. Mayoral Asensio, Roberto. 2004. Lenguajes de especialidad y traducción especializada. La traducción jurídica. In Consuelo Gonzalo (ed.). Documentación, terminología y traducción especializada, 49-71. Madrid: Arcos Libros.

Nord, Christiane. 2018. Translation as a purposeful activity. Functionalist approaches explained. London: Routledge.

Piecychna, Beata. 2013. Legal translation competence in the light of translational hermeneutics. Studies in Logic, Grammar and Rhetoric 34(47). 141-159.

Pommer, Sieglinde. 2008. Translation as intercultural transfer: The case of law. SKASE Journal of Translation and Interpretation 3(1). 17-21.

Prieto Ramos, Fernando. 2011. Developing legal translation competence: An integrative processoriented approach. Comparative Legilinguistics. International Journal for Legal Communications 5. 7-21.

Reiss, Katharina \& Hans Vermeer. 1996. Fundamentos para una teoría funcional de la traducción. Madrid: Akal.

Šarčević, Susan. 1997. New approach to legal translation. Dordrecht: Kluwer Law International.

Scarpa, Federica \& Daniele Orlando. 2017. What it takes to do it right. An integrative EMT-based model for legal translation competence. The Journal of Specialised Translation 27. 21-42.

Snell-Hornby, Mary. 1988. Translation studies. An integrated approach. Ámsterdam: Benjamins.

Soriano Barabino, Guadalupe. 2016. Comparative law for legal translators. Oxford: Peter Lang.

Soriano Barabino, Guadalupe. 2018. La formación del traductor jurídico: Análisis de la competencia traductora en traducción jurídica y propuesta de programa formativo. Quaderns: Revista de Traduccio 25. 217-229.

Soriano Barabino, Guadalupe. 2020. “Mamá, quiero ser traductor de textos jurídicos”. Pautas para la formación inicial en traducción jurídica. In Laura Sanfelici \& Ana-Isabel Foulquié-Rubio (eds.), Traducción e interpretación: entre investigación y didáctica, 211-226. Oxford: Peter Lang.

Tiersma, Peter. 1999. Legal language. Chicago: University of Chicago Press.

Trosborg, Anna. 1997. Text typology: Register, genre and text type. In Anna Trosborg (ed.). Text typology and translation, 3-23. Amsterdam/Philadelphia: John Benjamins.

Way, Catherine. 2014. Structuring a legal translation course: A framework for decision-making in legal translation training. In Le Cheng, King Kui Sin \& Anne Wagner (eds.), The Ashgate handbook of legal translation. Farnham: Ashgate.

Wilss, Wolfram. 1988. La ciencia de la traducción. Problemas y métodos. Mexico: Universidad Autónoma de México. 


\section{Bionote}

\section{Guadalupe Soriano Barabino}

Department of Translation and Interpreting, University of Granada, AVANTI Research Group, Granada, Spain

barabino@ugr.es

https://orcid.org/0000-0002-1134-981X

Guadalupe Soriano Barabino is Senior Lecturer in Translation at the University of Granada (Spain). She holds a PhD in Translation Studies (Legal Translation) as well as degrees in law and in translation and interpreting from the University of Granada. She has studied law in Spain, Ireland, the United Kingdom and France, worked as a solicitor in the United Kingdom and taught at the universities of Ulster, Salamanca and Granada. She also has extensive experience as a sworn translator and interpreter for English, French and Spanish. Her main areas of research are legal translation (including comparative law for legal translation) and interculturality. 